\title{
ANALISIS PERBAIKAN PROSES PRODUKSI PADA PT SUMBER TEKNIK SENTOSA
}

\author{
Damar Suryo Bowo \\ Department of Management FEB UMM \\ E-mail: damarsuryobowo@gmail.com
}

\begin{abstract}
This study aimed to analyze the production process of Dies Forging Piston Wheel Cylinder and to suggest the improvement for the production. The data were analyzed by Time-Function Mapping, Cause and Effect, and Failure Mode and Effect Analysis (FMEA). The findings showed that there were seven production phases of Dies Forging Piston Wheel Cylinder. After figuring out the troubled phase, the next step was searching for the cause and the solution of the problem using FMEA. The FMEA calculation indicated 4 problems i.e. the employees working on another product, vibrating clamp machines, employees producing jig, and unavailability of jig. The main problem was detected based on the highest score of Risk Priority Number (RPN) that calculation indicator was severity, occurrence, and detection.
\end{abstract}

Keywords: fishbone, FMEA, quality, time-function mapping, production process

\section{PENDAHULUAN}

Berkembangnya bisnis di Indonesia tidak lepas dari peran teknologi yang saat ini terus meningkat. Selain meningkatnya teknologi, faktor globalisasi juga memiliki peran terhadap berkembangnya bisnis di Indonesia. Tetapi adanya perkembangan teknologi dan globalisasi mengakibatkan persaingan bisnis di Indonesia meningkat.

Meningkatnya persaingan dalam dunia bisnis akan membuat konsumen semakin memiliki banyak pilihan dalam memilih produk. Karena itu, untuk memiliki daya saing dan bertahan terhadap persaingan dengan produk lain, perusahaan harus memiliki taktik dan strategi secara menyeluruh (La Hatani, 2007), artinya perusahaan harus memikirkan semua aspek yang bersangkutan dengan produk dan jasa yang akan dihasilkan guna memenangkan persaingan dengan industri lain termasuk dari segi proses produksi dan kualitas produknya.

Guna menghasilkan nilai tambah output untuk pelanggan, perusahaan atau suatu lingkungan mengintegrasikan secara berurutan dari manusia, material, metode, dan mesin atau peralatan yang dimiliki. Dalam merencanakan proses produksi, perusahaan harus memikirkan strategi proses dengan cermat karena strategi proses akan mempengaruhi kinerja, efektifitas, efisiensi, yang mana hal tersebut akan memiliki dampak yang berjangka panjang.

Pemilihan strategi proses bertujuan untuk menemukan suatu 
cara memproduksi barang dan jasa yang memenuhi persyaratan dari pelanggan dan spesifikasi produk yang ada di dalam batasan biaya dan batasan manajerial lainnya (Heizer dan Render, 2009). Salah memilih strategi proses yang akan diterapkan akan berdampak besar terhadap biaya yang dikeluarkan oleh perusahaan. Untuk itu perlu bagi perusahaan untuk menganalisis kegiatan produksinya agar dapat mencapai persyaratan perusahaan.

Dalam menganalisis kegiatan proses yang dilakukan oleh perusahaan, dapat menggunakan beberapa alat analisis salah satunya adalah pemetaan fungsi waktu. Pemetaan fungsi waktu digunakan untuk mengidentifikasi dan menghilangkan pemborosan dalam hal pengulangan, dan keterlambatan yang tidak perlu terjadi dalam proses produksi agar mengurangi kerugian yang ada dalam sebuah perusahaan.

Dalam proses produksi tentu memiliki banyak permasalahan yang dihadapi. Permasalahan permasalahan nantinya akan menyebabkan dampak negatif kepada perusahaan baik dari sisi kualitas produk maupun keefektifan suatu proses. Karena itu perusahaan harus menganalisis permasalahan yang terjadi dengan mengidentifikasikan penyebab penyebab dari permasalahan sehingga dapat mencegah permasalahan tersebut terjadi di masa mendatang. Menganalisa suatu permasalahan dapat menggunakan diagram sebab akibat.
Diagram Sebab Akibat ini berfungsi untuk mengidentifikasikan, memilah dan menampilkan penyebab dari suatu permasalahan yang terjadi (Heizer dan Render, 2009). Hasilhasilnya kemudian akan dicarikan solusi yang terbaik berdasarkan tingkat keparahan, keseringan dan kemampuan alat pengendalian yang terjadi di suatu proses menggunakan Failure Mode and Effect Analysis (FMEA). FMEA dapat menyediakan informasi yang terkait dengan permasalahan sehingga dapat membantu untuk memberikan solusi terkait dengan suatu permasalahan.

PT Sumber Teknik Sentosa (PT STS) merupakan perusahaan manufaktur yang bergerak dibidang pembuatan spare part machine dan special purpose machine. PT STS memproduksi berbagai macam spare part mesin, salah satu produk pesanannya adalah part mesin yangbernama Dies Forging Piston Wheel Cylinder (DFPWC).

Dari hasil wawancara pra penelitian didapatkan informasi bahwa ada keterlambatan terjadi pada proses produksi Dies Forging Piston Wheel cylinder. Hasil wawancara tersebut diperkuat dengan diketahuinya waktu target perusahaan, sehingga terlihat jelas keterlambatannya. Padahal manager PT STS mengatakan bahwa dalam memproduksi DFPWC, perusahaan telah mengkhususkan karyawan dan mesin tersendiri. Terdapat data keterlambatannya tersebut: 
Tabel 1. Data Keterlambatan Proses Produksi Dies Forging Piston Wheel

\begin{tabular}{cccc}
\multicolumn{4}{c}{ Cylinder } \\
\hline \multirow{2}{*}{ Nama Produk } & \multirow{2}{*}{ Bulan } & $\begin{array}{c}\text { Jumlah } \\
\text { Produk }\end{array}$ & Keterlambatan \\
\hline & & & $2,63 \mathrm{jam}$ \\
& Maret & 4 & $2,62 \mathrm{jam}$ \\
Dies Forging & & & $2,61 \mathrm{jam}$ \\
Piston Wheel & & & $2,64 \mathrm{jam}$ \\
Cylinder & April & 4 & $2,64 \mathrm{jam}$ \\
& & & $2,65 \mathrm{jam}$ \\
& & & $2,66 \mathrm{jam}$ \\
& & & $2,82 \mathrm{jam}$ \\
\hline
\end{tabular}

Data di atas membuktikan bahwa pada proses produksi Dies Forging Piston Wheel Cylinder terjadi permasalahan yang menyebabkan keterlambatan waktu dalam pembuatan produk.

Sesuai dengan permasalahan yang sudah dipaparkan di atas, maka rumusan masalah dalam penelitian ini adalah, pertama "Proses apa saja yang mengalami permasalahan waktu dalam produksi di PT Sumber Teknik Sentosa?. Rumusan masalah kedua adalah "faktor apa saja yang menjadi penyebab permasalahan sehingga menimbulkan permasalahan waktu dalam produksi di PT Sumber Teknik Sentosa?". Rumusan masalah ketiga yaitu "bagaimana solusinya untuk mengurangi permasalahan waktu dalam proses produksi”?

\section{TINJAUAN PUSTAKA}

Proses produksi yaitu suatu cara, metode ataupun teknik menambah kegunaan suatu barang dan jasa dengan menggunakan faktor produksi yang ada (Ahyari,2002).

Strategi proses adalah strategi operasi merupakan perumusan keputusan tentang desain proses menyangkut tentang pemilihan teknologi produksi, penentuan skala produksi, perencanaan dan pengendalian persediaan, serta pemilihan operasi (Hamind dan Nurnajamudin, 2011)

Menurut Yamit (2002) tipe proses produksi dibedakan menjadi tiga. Tipe pertama yakni proses produksi terus menerus. Tipe kedua adalah produksi terputus atau intermitten process. Tipe ketiga yakni proses produksi campuran.

Teori yang digunakan selanjutnya adalah analisis desain proses. Dalam mempertimbangkan desain proses, ada beberapa hal yang dipertimbangkan seperti manfaat kemampuan proses yang diajukan untuk menghilangkan langkah langkah yang tidak memberikan nilai tambah (Heizer dan Render, 2009).

Pemetaan fungsi waktu membantu pengguna untuk mengidentifikasi dan menghilangkan pemborosan seperti langkah tambahan, pengulangan, dan keterlambatan yang tidak memberikan niai tambah pada produk.

Kualitas dapat didefinisikan sebagai kemampuan perusahaan dalam memenuhi spesifikasi atas produk atau jasa yang telah ditetapkan oleh perusahaan (Heizer dan Render, 2009). Ada beberpa alat yang dapat digunakan untuk menganalisis kualitas. 
Menurut Heizer dan Render (2009) letak permasalahan kualitas dapat diketahui menggunakan alat atau teknik yang skematis. Alat ini menampilkan berbagai penyebab dari permasalahan, mengidentiaksikannya, dan kemudian memilahnya untuk mempermudah penggunanya.

Failure Mode and Effect Analysis (FMEA) menurut Gazperz (2002) merupakan alat yang sistematis yang berfungsi untuk mencegah sebanyak mungkin mode kegagalan. Menurutnya sumber sumber kegagalan dan akar penyebab dari suatu permasalahan dapat ditemukan dengan FMEA dengan mengidentifikasinya. FMEA terdiri dari beberapa indikator yakni severity, occurrence dan detection (Chysler, 2008)

Dalam penelitian ini memiliki tujuan yaitu untuk mengetahuiaktivitas bermasalah yang menyebabkan permasalahan waktu dalam proses, untuk mengetahui faktor faktor penyebab permasalahan yang mengakibatkan permasalahan waktu dan memberikan usulan untuk mencegah terjadinya permasalahan waktu didalam proses produksi.

Penelitian yang dilakukan oleh Gareth (2012) menghasilkan adanya pemborosan waktu yang terjadi pada saat penyediaan truk forklift. Penyedian truk forklift tertunda selama 30 menit karena truk harus melakukan pengisian bahan bakar.

Penelitian yang dilakukan Aniruda Josi dan Pritam Kadam (2014) menggunakan sebab akibat dan diagram pareto. Hasilnya menunjukan penyebab permasalahan yakni metode yang masih manual dan manusia yang ceroboh serta lalai.
Penelitian dengan metode sebab akibat juga digunakan oleh Haslindah (2013). Penelitian ini dilakukan di PT Jasuda yang hasil penelitiannya menunjukan adanya endapan dan gelembung yang disebabkan oleh kinerja yang rendah. Faktor yang menyebabkan permasalahan adalah bahan baku, metode dan kinerja mesin.

Penelitian menggunakan FMEA dilakukan oleh Rahmat Hidayat, Ishardita Pambudi, dan Remba Yanuar Efranto (2011). Hasil penelitian ini menunjukan ada 3 jenis waste yang teridentifikasi yakni product defect, waiting time, dan unnecessary inventory.

Fathi Wahyu Al Hafiis dan Ir. Hari Supriyanto (2008) juga melakukan penelitian menggunakan FMEA di PT Nestle Indonesia. Hasil penelitian menunjukan waste tertinggi terjadi di bagian dosing oil mix single evaporation dan penyebabnya adalah setting awal heater dan separator sedang dibersihkan. Solusi yang diberikan adalah controlling pada awal penerimaan barang, controlling pelaksanaan setting mesin, dan preventive maintenance yang teratur.

\section{METODE PENELITIAN}

Penelitian ini dilakukan di bagian produksi PT Sumber Teknik Sentosa. Metode pengumpulan data melalui observasi, wawancara dan dokumentasi. Jenis penelitian ini adalah aplikasi model, yakni penelitian yang menekankan pada pemecahan masalah masalah praktis yang diarahkan untuk menjawab pertanyaan spesifik dalam rangka penentuan kebijakan tertentu (Indriantoro dan Supomo, 2009). 
Populasi pada penelitian ini adalah total produk dies forging piston wheel cylinder pada bulan mei hingga juni 2017. Dengan cara mengamati seluruh proses yang dilakukan oleh karyawan dalam memproduksi produk.

Sebelumnya telah dilakukan pemetaan fungsi waktu yang hasilnya akan menemukan letak proses yang bermasalah. Selanjutnya adalah menggunakan diagram sebab akibat untuk mengidentifikasikan, memilah dan menampilkan berbagai penyebab dari permasalahan (Heizer dan Render, 2009).

Failure Mode and Effect Analysis (FMEA), Setelah mengetahui penyebab dari permasalahan, maka seluruh penyebab atau mode kegagalan akan diberikan nilai atau rating berdasarkan risk priority number (RPN). Kemudian dipilih nilai RPN yang paling tinggi untuk diberikan solusi atas mode kegagalan tersebut (Gazpers, 2002). Pemetaan fungsi waktu target adalah waktu dan aktivitas yang sudah tidak ada permasalahan didalamnya.

\section{HASIL DAN PEMBAHASAN}

Alat analisis yang digunakan pertama dalam penelitian ini adalah pemetaan fungsi waktu dasar untuk mengetahui letak atau dimana proses yang bermasalah. Adapun langkah langkah yang harus dilakukan adalah sebagai berikut

Langkah pertama adalah membuat alir divisi atau bagian. Dalam penelitian ini alir divisi nya adalah pelanggan memesan dan purchasing material. Kemudian setelah diketahui aktivitas aktivitas yang diketahui, selanjutnya adalah mencatat waktu dari setiap aktivitas. Berikut waktu dari tiap aktivitas proses produksi :

Tabel 2. Daftar Waktu Dari Tiap Aktivitas Proses DFPWC

\begin{tabular}{lllllllll}
\hline Aktivitas & $\begin{array}{l}\text { Waktu } \\
\text { DFPWC 1 }\end{array}$ & Hari & $\begin{array}{l}\text { Waktu } \\
\text { DFPWC 2 }\end{array}$ & Hari & $\begin{array}{l}\text { Waktu } \\
\text { DFPWC 3 }\end{array}$ & Hari & $\begin{array}{l}\text { Waktu } \\
\text { DFPWC 4 }\end{array}$ & Hari \\
\hline Menerima pesanan & 10 menit & Senin & 10 menit & Senin & 10 menit & Senin & 10 menit & Senin \\
Purchasing material & 1440 menit & Senin & 1440 menit & Senin & 1440 menit & Senin & 1440 menit & Senin \\
Bubut roughing part 1 & 76 menit & Selasa & 77 menit & Selasa & 76 menit & Selasa & 75 menit & Selasa \\
Bubut roughing part 2 & 71 menit & Selasa & 72 menit & Selasa & 72 menit & Selasa & 72 menit & Selasa \\
Bubut roughing part 3 & 115 menit & Selasa & 112 menit & Selasa & 113 menit & Selasa & 114 menit & Selasa \\
Heat Treatment & 2880 menit & Selasa & 2880 menit & Selasa & 2880 menit & Selasa & 2880 menit & Selasa \\
Bubut Semifinish part 1 & 111 menit & Kamis & 78 menit & Kamis & 77 menit & Kamis & 75 menit & Kamis \\
Bubut Semifinish part 2 & 70 menit & Kamis & 73 menit & Kamis & 71 menit & Kamis & 71 menit & Kamis \\
Bubut Semifinish part 3 3 & 40 menit & Jumat & 41 menit & Kamis & 41 menit & Kamis & 41 menit & Kamis \\
Assembling & 1440 menit & Jumat & 1440 menit & Kamis & 1440 menit & Kamis & 1440 menit & Kamis \\
Bubut Finishing & 124 menit & Sabtu & 123 menit & Sabtu & 124 menit & Sabtu & 124 menit & Sabtu \\
Miling & 25 menit & Sabtu & 25 menit & Sabtu & 25 menit & Sabtu & 25 menit & Sabtu \\
Taping & 25 menit & Sabtu & 25 menit & Sabtu & 25 menit & Sabtu & 25 menit & Sabtu \\
Grinding & 30 menit & Sabtu & 30 menit & Sabtu & 30 menit & Sabtu & 30 menit & Sabtu \\
Quality check & 15 menit & Sabtu & 15 menit & Sabtu & 15 menit & Sabtu & 15 menit & Sabtu \\
\hline
\end{tabular}


Data di atas didapatkan dari pekerja yang sama. Setelah pengamatan sebanyak empat kali mengetahui waktunya, selanjutnya proses produksi. Setiap proses bubut membuat diagram pemetaan fungsi dilakukan di mesin yang sama dan waktu.

Gambar 1. Pemetaan Fungsi Waktu Dasar

\begin{tabular}{|c|c|c|c|c|c|c|c|c|c|c|c|c|c|c|c|}
\hline Pelanggan & $\begin{array}{c}\text { Pesan } \\
1\end{array}$ & & & & & & & & & & & & & & Kirim \\
\hline Purchase & $\longrightarrow$ & $\begin{array}{l}\text { Beì } \\
\text { Material }\end{array}$ & & & & & & & & & & & & & $\uparrow$ \\
\hline Bubut & & & \begin{tabular}{|l|} 
Roughing \\
Pant 1
\end{tabular} & $\begin{array}{l}\text { Roughing } \\
\text { part } 2\end{array}$ & $\begin{array}{l}\text { Roughing } \\
\text { part } 3 \\
\end{array}$ & $\longrightarrow$ & $\begin{array}{l}\text { Semifinish } \\
\text { Part 1 }\end{array}$ & $\begin{array}{l}\text { Semifinish } \\
\text { Part } 2 \\
\end{array}$ & $\begin{array}{l}\text { Semifinish } \\
\text { Part } 3\end{array}$ & $\longrightarrow$ & Finish & & & & \\
\hline $\begin{array}{l}\text { Heat } \\
\text { treastment }\end{array}$ & & & & & 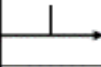 & Waiting & & & & & & & & & \\
\hline Assembling & & & & & & & & & $\longrightarrow$ & W'aiting & & & & & \\
\hline Taping & & & & & & & & & & & & 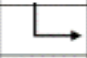 & \begin{tabular}{|l} 
Buzt \\
Ulir \\
\end{tabular} & & \\
\hline Surface & & & & & & & & & & & & & $\longrightarrow$ & Grinding & \\
\hline QC & & & & & & & & & & & & & & L & $\begin{array}{l}\text { All } \\
\text { chects }\end{array}$ \\
\hline $\begin{array}{l}\text { Tetal } \\
\text { wakktu }\end{array}$ & $\begin{array}{l}10 \\
\text { menit }\end{array}$ & $\begin{array}{l}1440 \\
\text { menit }\end{array}$ & $\begin{array}{l}35-77 \\
\text { menit }\end{array}$ & $\begin{array}{l}71-\gamma 2 \\
\text { menit }\end{array}$ & $\begin{array}{l}112-115 \\
\text { menit }\end{array}$ & $\begin{array}{l}2880 \\
\text { menit }\end{array}$ & $\begin{array}{l}75-111 \\
\text { menit }\end{array}$ & 30-73 menit & $40-41$ menit & $\begin{array}{l}1440 \\
\text { mernit }\end{array}$ & $\begin{array}{l}123- \\
124 \\
\text { menit }\end{array}$ & 25 menut & \begin{tabular}{|l|}
25 \\
menit
\end{tabular} & 30 ment: & $\begin{array}{l}15 \\
\text { menit }\end{array}$ \\
\hline
\end{tabular}

Artinya, ada satu orang yang memegang satu mesin, dan dua orang yang memegang dua mesin. Hal itu membuat pekerjaan di mesin lain sangat menumpuk apabila ada berbagai macam pesanan. Karena itu operator DFPWC yang hanya memegang satu mesin, selalu membantu pekerjaan karyawan lain.

Permasalahan kedua adalah karena operator mesin Dies Forging Piston Wheel Cylinder membuat jig juga karena tidak adanya operator khusus pembuat jig. Permasalahan ini muncul di semifinish part 1 . Permasalahan ketiga yakni tidak mengisi material tambahan karena operator lupa mengisi ulang di proses roughing part 1 .

Faktor selanjutnya yaitu karena mesin tidak memiliki fasilitas drawing design pada mesin yang muncul di setiap proses bubut sehingga mengharuskan karyawan mendesain di mesin lain dan clamp mesin yang rusak. Fasilitas drawing mesin merupakan fasilitas dimana operator dapat membuat atau menginput desain drawing yang sudah ada ke dalam settingan mesin. Pada mesin DFPWC yang digunakan tidak terdapat fasilitas tersebut sehingga operator harus menggunakan mesin lain untuk menginput desain dies.

Permasalahan kedua di mesin adalah permasalahan clamp mesin yang bergetar yang dapat disebabkan karena bearing pada rotor clamp kering sehingga putarannya terganggu. Permasalahan ini muncul di semifinish part 1 karena proses tersebut menggunakan clamp taper. Lebih spesifiknya clamp tidak dapat digunakan pada semifinish part 1 bagian inside diameter (ID).

Faktor selanjutnya adalah metode. Metode selalu berkaitan antara manusia dengan mesin karena metode adalah pedoman bagaimana proses harus dijalankan terhadap mesin. Permasalahan pertama pada metode adalah susunan pembuatan berubah karena proses semifinish menggunakan jig. Metode yang 
berubah adalah metode semifinish 1 dan 2. Faktor kedua permasalahan di metode karena tidak memberikan grease pada mesin yang disebabkan karena kurangnya perawatan atau tidak mengikuti SOP. Permasalahan ini muncul sebelum proses semifinish part 1 . Faktor ketiga di metode adalah karena mengantri di mesin lain untuk membuat desain. Mengantri terjadi disetiap proses bubut yaitu dari roughing part 1 hingga finishing.
Terakhir ada faktor material. Untuk material pembantu ada coolant salah satunya. Coolant di mesin sampai tidak keluar dari pemancar coolant karena coolant di mesin habis. Kejadian coolant habis terjadi pada proses roughing part 1. Selain itu, ada stok material jig yang kosong yang disebabkan karena tidak ada operator yang mengontrol persediaan jig. Berikut adalah gambar dari diagram pemetaan fungsi waktu
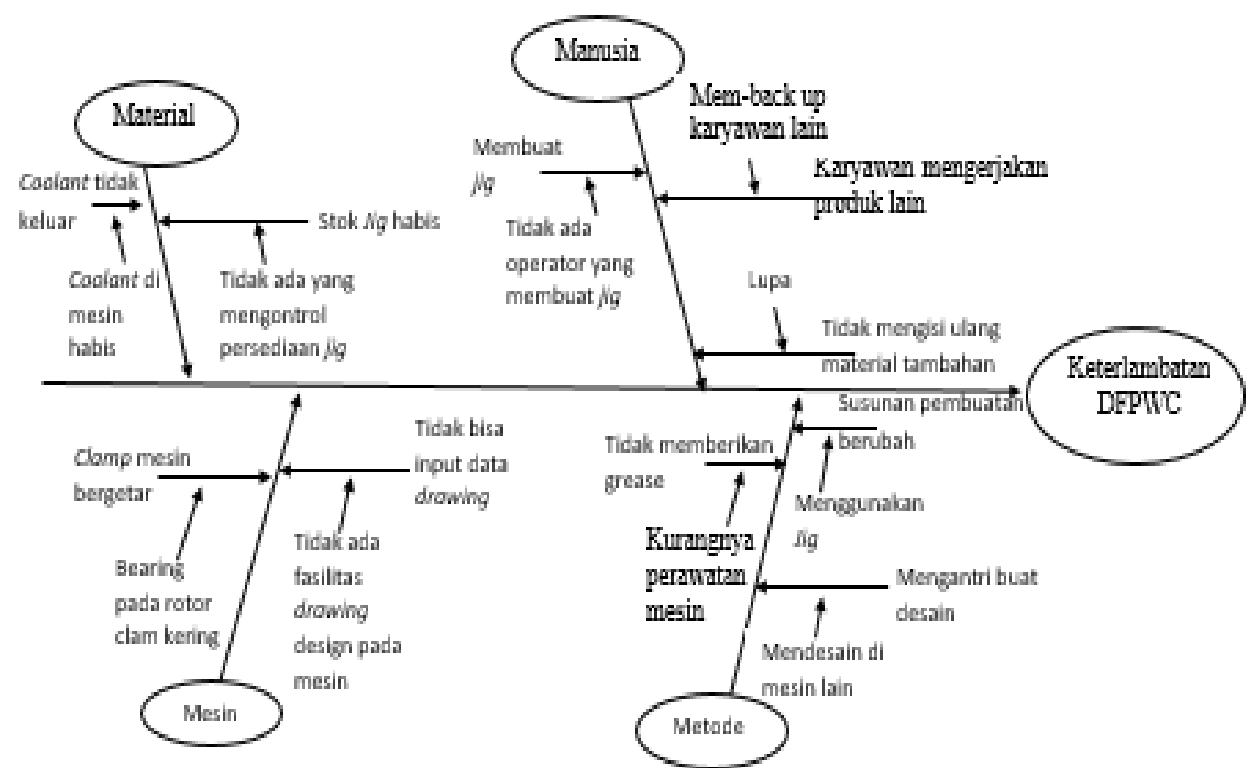

Gambar 2. Diagram Sebab Akibat Keterlambatan DFPWC

Penyebab penyebab di atas kemudian dihitung menggunakan alat analisis FMEA. Mencari nilai dari severity, occurrence, dan detection dari setiap failure mode yang ada. Kemudian dikalikan dan hasilnya akan disebut risk priority number (RPN) 
Tabel 5. Tabel FMEA Proses DFP

\begin{tabular}{|c|c|c|c|c|c|c|c|c|c|}
\hline No. & Failure Mode & Failure Effect & Sev & Causes & Occ & $\begin{array}{c}\text { Alat } \\
\text { Control }\end{array}$ & Det & $\mathrm{SxOxD}$ & RPN \\
\hline 1. & $\begin{array}{c}\text { Mengerjakan } \\
\text { produk lain di } \\
\text { mesin lain }\end{array}$ & $\begin{array}{l}\text { Terlambat di } \\
\text { semua proses }\end{array}$ & 8 & $\begin{array}{l}\text { Mem-back up } \\
\text { karyawan lain }\end{array}$ & 10 & $\begin{array}{c}\text { Tidak } \\
\text { ada }\end{array}$ & 10 & $8 \times 10 \times 10$ & 800 \\
\hline 2. & Membuat Jig & $\begin{array}{c}\text { Terlambat di } \\
\text { SF }\end{array}$ & 5 & $\begin{array}{c}\text { Tidak ada } \\
\text { operator } \\
\text { pembuat jig }\end{array}$ & 8 & $\begin{array}{c}\text { Tidak } \\
\text { ada }\end{array}$ & 10 & $5 \times 8 \times 10$ & 400 \\
\hline 3. & Stok Jig habis & $\begin{array}{c}\text { Terlambat di } \\
\text { SF }\end{array}$ & 5 & $\begin{array}{l}\text { Tidak ada yang } \\
\text { mengontrol } \\
\text { persediaan }\end{array}$ & 8 & $\begin{array}{c}\text { Tidak } \\
\text { ada }\end{array}$ & 10 & $5 \times 8 \times 10$ & 400 \\
\hline 4 & $\begin{array}{c}\text { Coolant tidak } \\
\text { keluar }\end{array}$ & $\begin{array}{c}\text { Terlambat di } \\
\text { RI }\end{array}$ & 2 & $\begin{array}{l}\text { Stok coolant di } \\
\text { mesin habis }\end{array}$ & 8 & SOP & 4 & $2 \times 8 \times 84$ & 64 \\
\hline 5. & $\begin{array}{l}\text { Clamp mesin } \\
\text { bergetar }\end{array}$ & $\begin{array}{c}\text { Terlambat di } \\
\text { SF }\end{array}$ & 5 & $\begin{array}{l}\text { Bearing pada } \\
\text { rotor clamp } \\
\text { kering }\end{array}$ & 5 & $\begin{array}{c}\text { Tidak } \\
\text { ada }\end{array}$ & 10 & $5 \times 10 \times 10$ & 500 \\
\hline 6. & $\begin{array}{l}\text { Tidak bisa input } \\
\text { data drawing }\end{array}$ & $\begin{array}{c}\text { Terlambat di } \\
\text { seluruh proses }\end{array}$ & 2 & $\begin{array}{c}\text { Tidak ada } \\
\text { fasilitas drawing } \\
\text { desain di mesin }\end{array}$ & 2 & SOP & 4 & $2 \times 10 \times 4$ & 80 \\
\hline 7. & $\begin{array}{l}\text { Tidak memberi } \\
\text { grease }\end{array}$ & $\begin{array}{l}\text { Terlambat di } \\
\text { SF }\end{array}$ & 5 & $\begin{array}{c}\text { Kurangnya } \\
\text { perawatan mesin }\end{array}$ & 5 & SOP & 4 & $5 \times 8 \times 4$ & 160 \\
\hline 8. & $\begin{array}{c}\text { Susunan } \\
\text { pembuatan } \\
\text { berubah }\end{array}$ & $\begin{array}{l}\text { Terlambat di } \\
\text { SF }\end{array}$ & 2 & $\begin{array}{l}\text { Menggunakan } \\
\text { jig }\end{array}$ & 2 & $\begin{array}{c}\text { Tidak } \\
\text { ada }\end{array}$ & 10 & $2 \times 10 \times 10$ & 200 \\
\hline 9. & $\begin{array}{c}\text { Mengatri sebuah } \\
\text { desain }\end{array}$ & $\begin{array}{c}\text { Terlambat di } \\
\text { seluruh proses }\end{array}$ & 2 & $\begin{array}{l}\text { Mendesain } \\
\text { dimesin lain }\end{array}$ & 2 & SOP & 4 & $2 \times 10 \times 4$ & 80 \\
\hline 10. & $\begin{array}{c}\text { Tidak mengisi } \\
\text { ulang material } \\
\text { tambahan }\end{array}$ & Material habis & 2 & Operator lupa & 2 & SOP & 4 & $2 \times 8 \times 4$ & 64 \\
\hline
\end{tabular}

Dilihat dari perkalian severity, occurance dan detection maka yang menjadi permasalahan prioritas yang terdiri dari permasalahan pada karyaan memback up pekerjaan laindengan nilai RPN 800, yang kedua adalah clamp mesin bergetar dgn nilai 500, yang ketiga karena membuat jig dan tidak ada stok jig dengan nilai masing masing 400 .

Ada cara untuk menanggulangi keterlambatan karena operator DFPWC mem-back up pekerjaaan karyawan lain yaitu dengan memvendorkan proses bubut produk lain yang pesanannya melebihi kemampuan sehingga tidak mengganggu jadwal produksi yang sudah direncanakan. Selain itu perusahaan dapat menambah jumlah operator sesuai dengan jumlah mesin yang ada.
Untuk permasalahan clamp mesin bergetar ada dua solusi, yaitu dengan selalu melakukan perawatan mesin khususnya clamp, dengan intensitas lebih sering danmenyeluruh. Solusi kedua adalah solusi dengan mengganti clamp yang rusak. Lalu untuk solusi membuat jig dan tidak ada stok jig adalah dengan membuat persedian jig minimal 1 jig disetiap bulannya apabila mesin masih rusak dan melakukan pengecekan rutin persedian jig setiap bulannya.

Setelah mengetahui solusi untuk setiap permasalahan prioritas, maka selanjutnya adalah membuat diagram pemetaan fungsi waktu target. Waktu tersebut diharapkan menjadi waktu yang terjadi dilapangan, sehingga tidak ada proses produksi DFPWC yang mengalami keterlambatan lagi kedepannya. 


\begin{tabular}{|c|c|c|c|c|c|c|c|c|c|c|c|c|c|c|c|}
\hline Pelanggan & Pesan & & & & & & & & & & & & & & Krim \\
\hline Purchise & $\longrightarrow$ & \begin{tabular}{|l|l} 
Bchi \\
Maserial
\end{tabular} & & & & & & & & & & & & & \\
\hline Bubst & & L & $\begin{array}{l}\text { Ropoting } \\
\text { Patt }\end{array}$ & $\begin{array}{l}\text { Roughing } \\
\text { p:at2 }\end{array}$ & $\begin{array}{l}\text { Rovothing } \\
\text { part 3 }\end{array}$ & $\Gamma$ & $\begin{array}{l}\text { Semifinish } \\
\text { Part } 1\end{array}$ & $\begin{array}{l}\text { Semifnimihh } \\
\text { part 2 }\end{array}$ & $\begin{array}{l}\text { Semifinith } \\
\text { Pant }\end{array}$ & $\vec{\Gamma}$ & Finish & & & & \\
\hline $\begin{array}{l}\text { Heat } \\
\text { treamsent }\end{array}$ & & & 1 & & & Waiting & & & & & & & & & \\
\hline Assembling & & & & & & & & & — & Waitirg & & & & & \\
\hline Malling & & & & & & & & & & & & $\begin{array}{l}\text { Butt } \\
\text { Lutbang }\end{array}$ & & & \\
\hline Taping & & & & & & & & & & & & $\longrightarrow$ & \begin{tabular}{|l|} 
Buaz: \\
Ulir
\end{tabular} & & \\
\hline Surface & & & & & & & & & & & & & $\longrightarrow$ & Grinting & \\
\hline QC & & & & & & & & & & & & & & $\longrightarrow$ & $\begin{array}{l}\text { 섹 } \\
\text { Chark }\end{array}$ \\
\hline $\begin{array}{l}\text { Total } \\
\text { azaksu }\end{array}$ & $\begin{array}{l}10 \\
\text { menit }\end{array}$ & $\begin{array}{l}\begin{array}{l}1440 \\
\text { mentit }\end{array} \\
\end{array}$ & 55 merit & 50 merrit & 80 mernit & $\begin{array}{l}28835 \\
\text { mentis }\end{array}$ & 55 mernt & $50 \mathrm{mrnait}$ & 25 memit & $\begin{array}{l}1410 \\
\text { menuit }\end{array}$ & $\begin{array}{l}90 \\
\text { menit }\end{array}$ & 25 mermit & \begin{tabular}{|l|l|}
25 \\
merat
\end{tabular} & $30 \mathrm{merain}$ & $\begin{array}{l}15 \\
\text { menit }\end{array}$ \\
\hline
\end{tabular}

Gambar 3. Pemetaan Fungsi Target

\section{KESIMPULAN}

Setelah penjelasan di bab 4, maka peneliti dapat menarik kesimpulan dalam beberapa hal yaitu proses yang menyebabkan keterlambatan adalah proses roughing part 1, roughing part 2 , roughing part 3 , semifinish part 1 , semifinish part 2 , semifinish part 3 dan proses finishing.

Penyebab permasalahan terdiri dari berbagai faktor yaitu faktor manusia seperti operator DFPWC memback up pekerjaan karyawan lain, lupa, dan membuat jig. Faktor material juga mempengaruhi keterlambatan dalam proses yaitu karena coolant di mesin habis, dan stok jig habis. Faktor mesin seperti clamp mesin bergetar dan tidak ada fasilitas drawing design. Terakhir karena faktor metode yaitu karena tidak memberikan grease pada mesin, susunan pembuatan berubah, dan mendesign di mesin lain.

Solusi atas permasalahan memback up karyawan lain yaitu dengan mem-vendorkan proses bubut produk lain yang pesanannya melebihi kemampuan perusahaan disaat proses produksi DFPWC sedang berjalan ke perusahaan lain. Solusi untuk mesin clamp yang rusak dalah dengan memperbaiki mesin yang rusak lalu membuat metode yang tepat untuk perawatan. Solusi untuk permasalahan membuat jig dan tidak ada stok jig adalah dengan menyediakan jig minimal 1 dengan membeli jig selama clamp mesin rusak dan melakukan pengecekan persediaan jig selama mesin rusak.

Untuk pihak manajamen PT Sumber Teknik Sentosa untuk selalu memperhatikan proses produksi Dies Forging Piston Wheel Cylinder agar tidak terjadi permasalahan waktu dalam proses produksi. Manager diharapkan untuk mem-vendorkan proses bubut produk lain yang pesanannya melebihi kemampuan perusahaan disaat proses produksi DFPWC sedang berjalan. Selain itu, ada solusi alternatif atas permasalahan operator memback up pekerjaan karyawan lain, yaitu dengan menambah jumlah pekerja 
sesuai dengan jumlah mesin yang ada.Membeli atau menyediakan jig terkait proses produksi. Untuk selalu melakukan pengontrolan persediaan jig. Memperbaiki clamp mesin yang rusak dan melakukan perawatan secara rutin dan menyeluruh.

Bagi penelitian selanjutnya Untuk meneliti seluruh produk di PT Sumber Teknik Sentosa. Selain itu dapat menambahkan faktor mother nature/environtment dan measurement dalam faktor penyebab permasalahan di diagram sebab akibat sesuai dengan teori Scarvada tahun 2004.

\section{DAFTAR PUSTAKA}

Al Hafiish, Fathy Wahyu dan Hari Supriyanto. 2008. Peningkatan kualitas dengan Pendekatan Konsep Lean dan Multi Atribute Failure Mode Analysis. http://digilib.its.ac.id/public/ITSUndergraduate-10673-Paper.pdf. Diakses pada 20 Januari 2017.

Aniruddha joshi dan pritam kadam.2014. An application of pareto analysis and cause effect diagram for minimization of defects in manual casting process

Arikunto, Suharsimi. 2010. Metodologi Penelitian. Jakarta : PT Rineka Cipta.

Chrysler Corporation, Ford Motor Company, General Motor Corporation. 2008. Potential Failure and Effect Analysis (FMEA) Reference Manual. Fourth Edition.

Gareth (2012). Extension of process mapping to identify "green waste"

Gasperz, Vincent. 2002. Pedoman Implementasi Program Six Sigma Terintegrasi dengan ISO 9001, MBNQA, dan HACCP. Jakarta : PT Gramedia Pustaka Utama.

Haming, Murdifin dan Mahmud Nurnajamudin. 2011. Manajemen Produksi Modern. Jakarta : Sinar Grafika Offset.

Haslinda, A.2013. Analisa Pengendalian Mutu Minuman Rumput Laut dengan Menggunakan Metode Fishbone Chart pada PT. Jasuda di Kabuten Talakar. http://iltekuim.org/jurnal/jurnal/3. \%20A.\%20haslindah\%20(5).pdf. Diakses tanggal 15 Februari 2017 Heizer, Jay and Barry Render. 2009. Operations Management (Manajemen Operasi ). Edisi 9. Jakarta : Salemba Empat.

Hidayat, Rahmad, Pambudi Tama, dan Remba Yanuar Efranto. 2011. Penerapan Lean Manufacturing dengan Metode VSM dan FMEA Untuk Mengurangi Waste pada Produk Plywood.http://jrmsi.studentjourn al.ub.ac.id/index.php/jrmsi/article /viewFile/148/193. Diakses pada 17 Januari 2017

Indriantoro, Nur dan Bambang Supomo. 2009. Metode Penelitian Bisnis Untuk Akuntansi dan Manajemen. Edisi Pertama. Yogyakarta : BPFEYogyakarta.

Yamit, Zulian. 2002. Manajemen Kualitas Produk dan Jasa.Yogyakarta: Ekonosia. 